\title{
Selection and Characterization of a Single-Chain Variable Fragment against Porcine Circovirus Type 2 Capsid and Impedimetric Immunosensor Development
}

\author{
Supaporn Klangprapan, Chang-Ching Weng, Wan-Ting Huang, Yaw-Kuen Li, \\ and Kiattawee Choowongkomon*
}

Cite This: ACS Omega 2021, 6, 24233-24243

Read Online
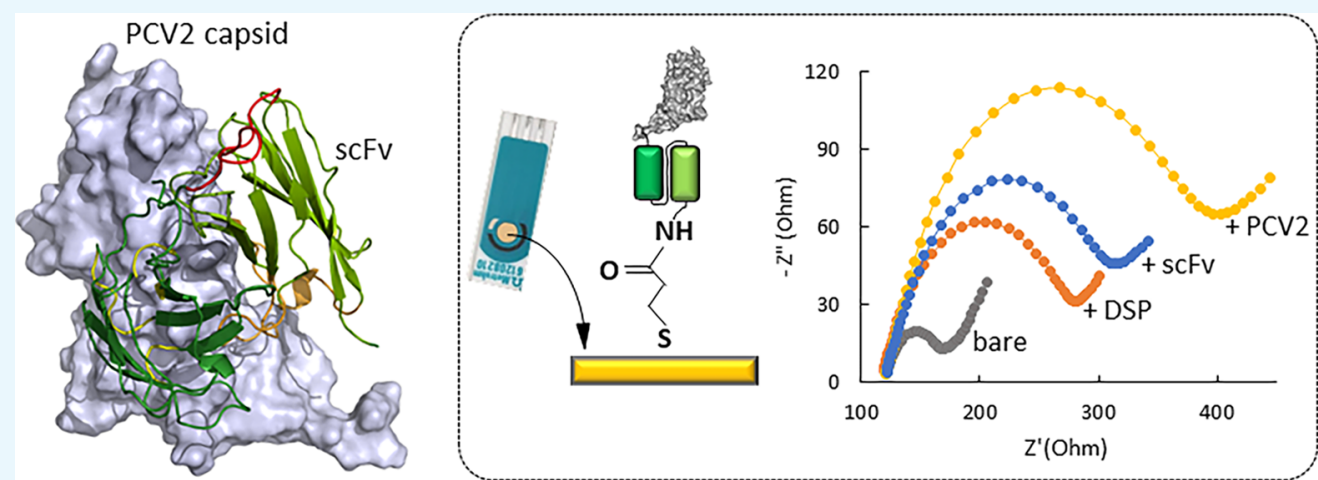

ABSTRACT: Porcine circovirus type 2 (PCV2) is the primary causative agent of porcine circovirus-associated disease (PCVAD) that causes huge global economic losses for the swine industry. Effective strategies or rapid detection of PCV2 in pig are essential to control PCVAD. Here, single-chain variable fragments ( $\mathrm{scFvs}$ ) were selected and characterized against the PCV2 capsid using phage display technology. Phage scFv clones were selected from the human scFv phagemid library (Tomlinson I $+\mathrm{J}$ ) for direct panning against the PCV2 capsid. Eighty-four monoclonal phage scFvs were individually tested for binding to the PCV2 capsid by ELISA. Eight scFv clones showed significant binding to the PCV2 capsid and only three clones (clone nos. 13, 37, and 81) contained both VHCDRs and VLCDRs in the sequence. Clone scFv no. 81 had the highest reactivity to the PCV2 capsid and was constructed in the pET22b (+) expression vector. The recombinant was transformed to Escherichia coli BL21(DE3) for expression and purification. The scFv showed appropriate affinity to the PCV2 capsid by western blot analysis. Kinetics of scFv and the PCV2 capsid were determined using surface plasmon resonance and showed binding affinity in the nanomolar range $\left(K_{\mathrm{D}}=57.2 \mathrm{nM}\right)$. Our scFv was first applied in the development of an impedimetric immunosensor for PCV2 capsid detection, and results showed that impedance increased with increasing PCV2 capsid expression with limit of detection $=114 \mathrm{nM}$. Findings demonstrated that our scFv has potential for use as a receptor for biosensor devices.

\section{INTRODUCTION}

Porcine circovirus type 2 (PCV2) is a small non-enveloped virus, with a single-stranded circular DNA genome approximately $1.7 \mathrm{~kb}$ in length as a member of the genus Circovirus, family Circoviridae. ${ }^{1}$ PCV2 causes circovirus disease and endemic infection of swine. Diseases associated with PCV2 have a significant impact on swine populations worldwide. ${ }^{2-5}$ Epidemiologic research on endemic infection has shown the rapid global spread of virulent PCV2.$^{6-8} \mathrm{PCV} 2$ is the primary causative agent of porcine circovirus-associated disease (PCVAD) composed of post-weaning multisystemic wasting syndrome (PMWS), ${ }^{9}$ porcine dermatitis and nephropathy syndrome (PDNS), porcine respiratory disease complex (PRDC), and reproductive failure. ${ }^{10}$ PMWS-affected piglets between 8 and 16 weeks old exhibit symptoms including jaundice, weight loss, difficulty in breathing, enlarged lymph nodes, and diarrhea. ${ }^{11}$ Multiple PCV2 vaccines are available for disease prevention that generate an immune response against the viral capsid. ${ }^{12-14}$ However, antibody levels of piglets at the time of vaccination may be low or non-existent, and a protocol is required to determine the optimal time for early inoculation.

Received: July 22, 2021

Published: September 10, 2021 
The PCV genome has two major open reading frames (ORFs). ORF1 is essential for viral replication, while ORF2 encodes the major capsid as the protein structural shell of the virus (21). The ORF2 protein contains type-specific epitopes (22). PCV2 has a supramolecular structure formed by twelve pentamers of a single protein called Cap. The primary structure of this protein consists of 233-234 amino acid residues, with a molecular mass of approximately $28 \mathrm{kDa}^{15-17}$ The PCV2 capsid is involved in the host protective response system and is a target for vaccine and diagnostic reagent development.

Diagnostic testing of the PCV2 capsid is useful for monitoring infection and helps swine farmers to assess whether there are subpopulations and implement strategies to homogenize the immune status of the breeding herd. Many tools are available for detection of PCV2 including quantitative polymerase chain reaction (PCR) that is widely used to detect PCV2 in serum samples, ${ }^{18}$ immunoperoxidase monolayer assay (IPMA), western blotting, enzyme-linked immunosorbent assay (ELISA), ${ }^{19,20}$ and surface plasmon resonance (SPR). ${ }^{21}$ These methods require antibodies specific to the PCV2 capsid protein. There are polyclonal antibodies which sometimes show nonspecific reactivity, while monoclonal antibodies provide highly specific reactions. Thus, selection of highquality antibodies is an important issue for increasing the specificity and sensitivity in immunoassay methods.

Phage display is a selection technique whereby a peptide or protein is fused with a bacteriophage coat protein and displayed on the surface of a virion ${ }^{22}$ as a popular approach for high-throughput screening of protein interactions. This technique is used to produce the specific antibody fragments such as single-domain variable heavy chain nanobodies $(\mathrm{VHHs})^{31}$ and single-chain variable fragment $(\mathrm{scFv}) . \mathrm{scFv}$ is the most commonly used type of the recombinant antibody. It composes of $\mathrm{VH}$ and VL domains that function in antigenbinding activities. ${ }^{23}$ In a previous report, $\mathrm{scFv}$ has been used for detection of various targets such as Bacillus thuringiensis Cry1F toxin, ${ }^{24}$ Helicobacter pylori VacA toxin, ${ }^{25}$ tumor necrosis factor-receptor; $4-1 \mathrm{BB},{ }^{26}$ and Chickpea chlorotic dwarf virus $^{27}$ However, to the best of our knowledge, phage display $\mathrm{scFv}$ for the PCV2 capsid has never been reported.

Electrochemical biosensors are now an essential component of medical diagnostics. ${ }^{28}$ Electrochemical impedance spectroscopy (EIS) is a sensitive electrochemical technique used for detecting biomolecular interactions occurring at the electrode surface. Impedance changes occur from incremental depositions on the working electrode surface such as bioreceptor and target-bioreceptor complexes. ${ }^{29}$ The EIS technique has shown promise in quantifying molecules using antibodies as recognition molecules on electrodes or cell impedimetric immunosensors including bacteria, viruses, parasites, and inflammatory markers. ${ }^{30-34}$ EIS offers a powerful, informative, and fast electrochemical response, with non-destruction of the target, simple operation, and low cost. Thus, this technique has gained widespread application.

This study selected scFvs against the PCV2 capsid from the human scFv phagemid library (Tomlinson $\mathrm{I}+\mathrm{J}$ ) using phage display technology. The scFv reactivity was characterized by ELISA, western blot, and SPR analysis to develop scFv impedimetric immunosensors based on EIS for PCV2 capsid detection.

\section{MATERIALS AND METHODS}

2.1. scFv Phage Library Biopanning. One hundred microliters of $5 \mu \mathrm{g} / \mathrm{mL}$ PCV2 capsid protein (Sino Biological Inc.) were coated onto a 96-well plate and incubated at $4{ }^{\circ} \mathrm{C}$ overnight. Blocking was performed with $1 \%$ BSA in $10 \mathrm{mM}$ PBS and incubated at room temperature for $2 \mathrm{~h}$. Then, $100 \mu \mathrm{L}$ of phage $\left(1 \times 10^{12}\right)$ from human scFv phagemid library (Tomlinson $\mathrm{I}+\mathrm{J}$ ) was added into the wells and incubated for 1 h. The plate was washed with $0.1 \%$ Tween-20 in PBS to remove unbound phage 10 times. The bound phages were eluted by adding $100 \mu \mathrm{L}$ of trypsin $(1 \mathrm{mg} / \mathrm{mL})$ and incubated for $15 \mathrm{~min}$ on a shaker. The bound phage was filtrated using a $0.22 \mu \mathrm{m}$ filter membrane and infected with Escherichia coli XL1 Blue. The bacteria were cultured in the $2 \mathrm{xTY}$ agar plate $(1.6 \%$ tryptone, $1 \%$ g yeast extract, and $0.5 \% \mathrm{NaCl}$ ) with $10 \mu \mathrm{g} / \mathrm{mL}$ tetracycline and $1 \%$ glucose, incubated at $37{ }^{\circ} \mathrm{C}$ for $30 \mathrm{~min}$, and then plated in $2 \mathrm{xTY}$ (containing $100 \mu \mathrm{g} / \mathrm{mL}$ ampicillin) at $37{ }^{\circ} \mathrm{C}$ for $16 \mathrm{~h}$. The polyclones from the first round of selection were amplified for further rounds (Figure S1).

Monoclonals found after the first round of selection were amplified for ELISA screening as follows. Individual phageinfected E. coli XL1 Blue colonies were grown in a 96-well plate containing $100 \mu \mathrm{L}$ of 2 xTY (containing $100 \mu \mathrm{g} / \mathrm{mL}$ ampicillin, $0.1 \%$ glucose) and shaken at $37{ }^{\circ} \mathrm{C}$ until the $\mathrm{OD}_{600}$ reached 0.4. The KM703 helper phage was infected into the cell and incubated at $37{ }^{\circ} \mathrm{C}$ for $30 \mathrm{~min}$. The pellet was collected by centrifugation at $3000 \mathrm{rpm}$ for $30 \mathrm{~min}$, plated into $2 \mathrm{xTY}$ (containing $100 \mu \mathrm{g} / \mathrm{mL}$ ampicillin, $50 \mu \mathrm{g}$ kanamycin and $0.1 \%$ glucose), and incubated at $30{ }^{\circ} \mathrm{C}$ overnight with shaking. The next day, purification was performed by centrifugation of the phage suspension at $4{ }^{\circ} \mathrm{C}, 3000 \mathrm{rpm}$ for $2 \mathrm{~h}$. The supernatant was collected and precipitated by adding $4 \%$ polyethylene glycol in $25 \mathrm{mM} \mathrm{NaCl}$ and incubated at $4{ }^{\circ} \mathrm{C}$ for $1 \mathrm{~h}$. The precipitated phage was further centrifuged at $3000 \mathrm{rpm}$ for 30 min. The phage pellet was collected, resuspended with PBS, and maintained at $4{ }^{\circ} \mathrm{C}$ until required for the next experiment.

2.2. ELISA Screening for Phage scFv Specific to PCV2 Capsid. A 96-well plate was coated with $100 \mu \mathrm{L}$ PCV2 capsid $(5 \mu \mathrm{g} / \mathrm{mL})$ and incubated overnight at $4{ }^{\circ} \mathrm{C}$. The next day, 200 $\mu \mathrm{L}$ of washing buffer (0.05\% Tween-20 in $1 \times \mathrm{PBS} \mathrm{pH} 7.4)$ was added to remove excess protein and washed three times. Then, $200 \mu \mathrm{L}$ of blocking buffer (1\% BSA in $1 \times$ PBS $\mathrm{pH} 7.4$ ) was further added for $2 \mathrm{~h}$. Each phage $\mathrm{scFv}$ was added to the blocked well and incubated for $1 \mathrm{~h}$. Then, $100 \mu \mathrm{L}$ of HRPconjugated anti-M13 antibody (1:2000 dilution) was added and the sample was incubated at room temperature for $1 \mathrm{~h}$. To indicate the reactivity of individual phages of $\mathrm{scFv}$ binding to PCV2, $100 \mu \mathrm{L}$ TMB with $1 \%$ of $\mathrm{H}_{2} \mathrm{O}_{2}$ as the substrate for HRP was added in each well and incubated in a dark area to develop the blue color. Then, $100 \mu \mathrm{L}$ of $1 \mathrm{M}$ of HCL was added to stop the peroxidation reaction. The blue color turned to yellow and absorbance at wavelength $450 \mathrm{~nm}$ was measured using an ELISA plate reader. All incubation steps were performed at room temperature, except for protein coating on the first day. Positive monoclonal bacteria were isolated for sequencing. The phage-scFv81, one of the potential phages, was diluted to concentration $2.6 \times 10^{-4}$ to $5.0 \times 10^{6} \mathrm{cfu} / \mathrm{mL}$ and subjected to ELISA testing for PCV2 capsid compared with BSA as the negative control.

2.3. Construction of scFv Expression Vectors. The $\mathrm{scFv} / \mathrm{pIT} 2$ phagemids were extracted, and $\mathrm{scFv}$ was amplified using a Kapa Hifi Kit with LMB3 as forward primer 
(5'CAGGAA ACA GCT ATG AC $3^{\prime}$ ) and pHEN as the reverse primer (5'CTA TGC GGC CCC ATT CA $\left.3^{\prime}\right)$. The amplified scFv products were confirmed for size by $2 \%$ agarose gel. To prepare the inserted gene and vector, the $\mathrm{scFv}$ gene and pET22b (+) vector were cut using restriction enzyme Ncol and Notl and then confirmed for size by $2 \%$ agarose gel. The scFv and $p E T 22 b(+)$ vector contained in the gel were further purified by a purification kit, and concentration was measured by a nanodrop spectrophotometer. The ligation reaction of recombinant $\mathrm{scFv} / p E T 22 b+$ was performed with ratio $(\mu \mathrm{L})$ of insert gene/pET22b(+)/T4 ligase/buffer A/buffer B (0.3:6.7:1:1:1), incubated at $20{ }^{\circ} \mathrm{C}$ for $30 \mathrm{~min}$. The recombinant gene was further transformed into the $D H 5 \alpha$ competent cell. Individuals of inserted $\mathrm{scFv}$ in $p E T 22 b(+)$ clone were confirmed by colony PCR with T7 as forward and reverse primer and confirmed for product size by $2 \%$ agarose gel. The clones with $\mathrm{scFv}$ genes were further grown in the $2 \mathrm{xTY}$ agar plate, and the scFv/pET22b (+) plasmid was extracted by sequencing confirmation.

2.4. scFv Expression and Purification. The recombinant $\mathrm{scFv}$ with $6 \mathrm{xHis}$ tag was expressed in E. coli BL21(DE3). The strains containing the expression plasmid were propagated overnight at $37{ }^{\circ} \mathrm{C}$ in $3 \mathrm{~mL}$ Luria-Bertani (LB) (seed) medium containing $100 \mu \mathrm{g} / \mathrm{mL}$ of ampicillin. Then, $1 \%$ of seed was added to $500 \mathrm{~mL} \mathrm{LB}$ broth containing $100 \mu \mathrm{g} / \mathrm{mL}$ of ampicillin and incubated at $37{ }^{\circ} \mathrm{C}$ for around $4 \mathrm{~h}$ to reach $\mathrm{OD}_{600}=1.0$. Then, isopropyl $\beta$-D-thiogalactopyranoside (IPTG) was added to a final concentration of $0.4 \mathrm{mM}$ and incubated overnight for $20 \mathrm{~h}$ at $16{ }^{\circ} \mathrm{C}$. Next day, the cells were collected by centrifugation at $4{ }^{\circ} \mathrm{C}, 3000 \mathrm{rpm}$ for $15 \mathrm{~min}$. Cell pellets were then resuspended in $20 \mathrm{~mL}$ of $1 \times$ PBS buffer $\mathrm{pH}$ 7.4 and further sonicated for $30 \mathrm{~min}$ on ice to disrupt the cells. The cell homogenate was centrifuged at $4{ }^{\circ} \mathrm{C}, 10,000 \mathrm{~g}$ for 30 min. Then, the supernatant was collected and purified using cation exchange, followed by HisPurTM Ni-NTA Resin. scFv fragments were analyzed for size by sodium dodecyl sulfate polyacrylamide gel electrophoresis (SDS-PAGE) under reduced condition, with bands observed after staining with Coomassie Blue.

2.5. Western Blot Analysis. To confirm the size, $s c F v$ in SDS-PAGE gel was transferred into the polyvinylidene fluoride (PVDF) membrane for $30 \mathrm{~min}$ and blocked with TSW buffer pH $7.4(10 \mathrm{mM}$ Tris, $0.9 \% \mathrm{NaCl}, 0.25 \%$ gelatin, $0.1 \%$ Triton $\mathrm{x}-100,0.02 \% \mathrm{SDS}$ ) for $1 \mathrm{~h}$. The scFv fragments were detected with $3000 \times$ diluted anti His antibody for $1 \mathrm{~h}$, then washed and further incubated in $3000 \times$ diluted anti mouse IgG HRP for 1 $h$, and washed to remove the unreacted antibody. HRP was visualized with enhanced chemiluminescence (ECL), a luminol-based substrate for HRP.

To prove scFv binding to the PCV2 capsid, equal volumes of the PCV2 capsid (150 ng/well) were electrophoresed onto SDS-PAGE, with 4 wells of PCV2 capsid loaded for different antibody detection and transferred into the PVDF membrane. The PCV2 capsid antigen in the membrane was then detected by antibody mentioned as follows: (1) used $1^{\circ}$ antibody:purified $\mathrm{scFv}(0.05 \mathrm{mg} / \mathrm{mL}), 2^{\circ}$ antibody:anti His antibody (mouse monoclonal), $3^{\circ}$ antibody:anti mouse IgG-HRP, (2) used $1^{\circ}$ antibody:phage $\mathrm{scFv}\left(2.6 \times 10^{6} \mathrm{cfu} / \mathrm{mL}\right), 2^{\circ}$ antibody:anti M13 HRP, and (3) used $1^{\circ}$ antibody:commercial anti PCV2 (rabbit polyclonal), $2^{\circ}$ antibody anti rabbit IgGHRP.

2.6. Interaction Analysis. The SWISS-MODEL (https:// swissmodel.expasy.org/) was used to obtain the 3D structure of $\mathrm{scFv}$, with the 3D structure of the PCV2 capsid obtained from the protein databank (PDB ID: 3JCI). The quality of the 3D scFv model was checked by PROCHECK. Identification of the potential binding interface of $s c F v$ to the PCV2 capsid and protein-protein docking was performed by the program Frodock version 2.0. ${ }^{35}$ Molecular interaction between $\mathrm{scFv}$ and the PCV2 capsid was visualized by PyMOL software version 1.3 .

2.7. Kinetics and Affinity Determination by SPR. Binding kinetics of $\mathrm{scFv}$ to the PCV2 capsid was measured by SPR (OpenSPR, Nicoya Lifesciences) at $25^{\circ} \mathrm{C}$. The ligand was activated for $\mathrm{COOH}$ groups by mixing $100 \mu \mathrm{L}$ of $0.030 \mathrm{mg} /$ $\mathrm{mL} \mathrm{scFv}$ in $10 \mathrm{mM}$ PBS $\mathrm{pH} 7.4$ (running buffer), $50 \mu \mathrm{L}$ of 0.2 $\mathrm{M}$ EDC, and $50 \mu \mathrm{L}$ of $0.05 \mathrm{M} \mathrm{NHS}$, incubated at $4{ }^{\circ} \mathrm{C}$ for $1 \mathrm{~h}$. All measurements were performed in running buffer. The $\mathrm{NH}_{2}$ sensor chip surface (Nicoya Lifesciences) was loaded into an OpenSPR instrument and performed for baseline. To immobilize $\mathrm{scFv}$ on $\mathrm{NH}_{2}, 200 \mu \mathrm{L}$ of coupled scFv/EDC/ NHS was injected at a flow rate of $10 \mu \mathrm{L} / \mathrm{min}$ and dissociated for $5 \mathrm{~min}$. Then, $200 \mu \mathrm{L}$ of blocking was injected to inactivate non-immobilized scFv. Various concentrations of the PCV2 capsid were performed $(5.52-176 \mathrm{nM})$ and injected at $200 \mu \mathrm{L}$ with a flow rate of $10 \mu \mathrm{L} / \mathrm{min}$ and dissociated for $2 \mathrm{~min}$. Kinetic data were fitted and analyzed by Trace Drawer version 1.6.1 using the 1:1 binding model, and respective rate constant values were calculated. All measurements were performed in triplicate.

2.8. Impedimetric Immunosensor. EIS was detected using a PalmSens4 Potentiostat (Zahner, Germany). The modified process was adapted from Cordeiro and Chinnadayyala. ${ }^{36,37}$ Bare gold electrodes (Metrohm) were initially cleaned with DI water, pre-treated by immersion in $0.1 \mathrm{M}$ $\mathrm{NaCl}$ for $5 \mathrm{~min}$, and measured for impedance as a reference electrode. Then, $5 \mu \mathrm{L}$ of $20 \mathrm{mM}$ disodium phosphate (DSP) in 99\% DMSO was dropped onto the working electrode for $2 \mathrm{~h}$ and rinsed in DI water to remove unbound DSP. The modified electrode was further immobilized with $5 \mu \mathrm{L}$ of $0.121 \mathrm{mg} / \mathrm{mL}$ $\mathrm{scFv}$ for $1 \mathrm{~h}$ at $4{ }^{\circ} \mathrm{C}$ and washed to remove unreacted scFv. A schematic diagram of immunosensor fabrication is shown in Figure 7A. Then, different concentrations of the PCV2 capsid $35-704 \mathrm{nM}$ in $10 \mathrm{mM}$ PBS ( $\mathrm{pH} 7.4$ ) were dropped onto the modified electrode for $30 \mathrm{~min}$ at room temperature and washed to remove the unbound PCV2 capsid. All measurements were performed by dropping $100 \mu \mathrm{L}$ of the $5 \mathrm{mM}$ $\left[\mathrm{Fe}(\mathrm{CN})_{6}\right]^{4-/ 3-}$ redox probe covering three electrodes (working, reference ,and counter) as the background electrolyte. The impedance was scanned by inserting the modified electrode into a potentiostat, and the result was displayed by program PSTrace version 5.7 with parameters set as T equilibration:3 s, Edc:0.08961 V, Eac:0.005 V, N frequency:73:12/dec, Max frequency:100,000 Hz, Min frequency:0.1 Hz. Results are presented as Nyquist plots, with the complex impedance displayed as the sum of the real and imaginary components $\left(Z^{\prime}\right.$ and $Z^{\prime \prime}$, respectively).

\section{RESULTS}

3.1. Screening of scFvs by Biopanning. Monoclones of the scFv phage-bounded PCV2 capsid were found on the $2 \mathrm{xTY}$ agar plate after the first round of biopanning that was performed in triplicate, with approximately 20 clones on each plate. Eighty-four individual colonies from the three plates were collected for propagation by helper phage KM703. 

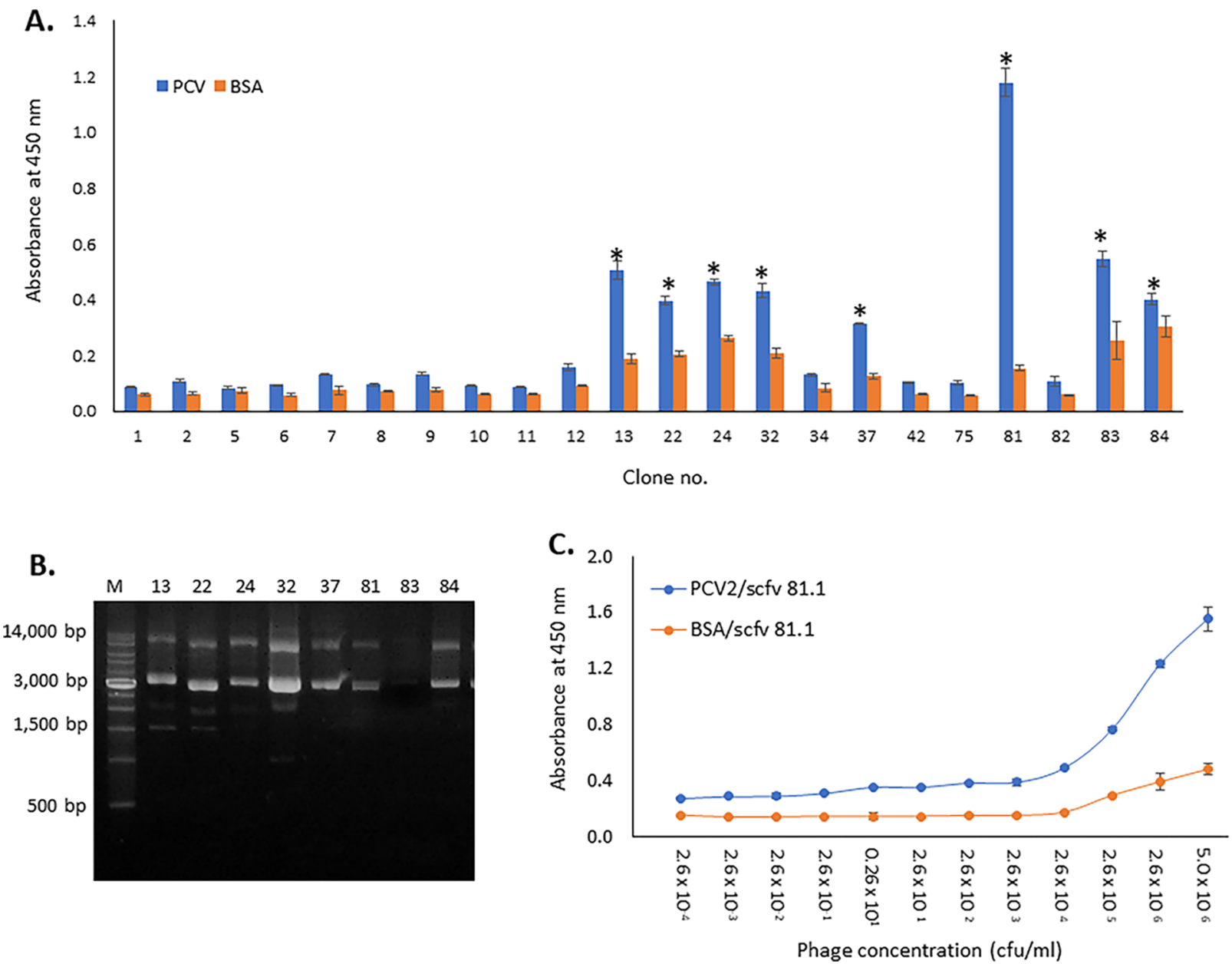

Figure 1. ELISA screening of individual phage-scFv specific to the PCV2 capsid. (A) Binding of phage scFv determined by ELISA against the PCV2 capsid. The PCV2 capsid was coated onto 96-well microtiter plates. Each phage scFv was detected using an HRP-conjugated anti-M13 antibody and TMB substrate solution. ELISA readings (OD450) were collected after 30 min incubation in the TMB substrate at $25{ }^{\circ} \mathrm{C}$. Eight positive clones (*) were further collected for plasmid extraction. (B) Agarose gel of the scFv/pIT2 plasmid extracted from E. coli XL1 blue. (C) ELISA experiment using different concentrations of phage scFv 81 bound to the PCV2 capsid compared to BSA.

The ELISA was used for screening positive clones using an HRP-conjugated anti-M13 antibody since the scFv proteins which were displayed on the phages also have M13-tag on the $\mathrm{C}$-terminal of the sequences. Binding of selected $\mathrm{scFv}$ phages with the PCV2 capsid was quantitatively confirmed using an HRP-conjugated anti-M13 antibody by measuring the absorbance at $450 \mathrm{~nm}$. Results showed significant binding of the $\mathrm{scFv}$ phage to PCV2 capsid, especially phage nos. 13, 22, 24, 32, 37, 81, 83, and 84 (Figure 1A). The eight positive clones were then collected for plasmid extraction sequencing using agarose gel, as shown in Figure 1B. Clone no. 81 showed the highest binding to the PCV2 capsid $\left(\mathrm{OD}_{450}=1.115\right)$ and less interaction with BSA. Various concentrations of phage $\mathrm{scFv} 81$ from $2.6 \times 10^{-4}$ to $5.0 \times 10^{6} \mathrm{cfu} / \mathrm{mL}$ against the fixed concentration of the PCV2 capsid (100 ng/well) were measured by ELISA. Results showed that binding activity of phage scFv to PCV2 capsid was significantly higher than phage $\mathrm{scFv}$ bound to BSA control (Figure 1C). Furthermore, increasing phage $\mathrm{scFv}$ concentration increased the binding complex of the scFv/PCV2 capsid, as shown by the increase in $\mathrm{OD}_{450}$. Thus, concentration of $2.6 \times 10^{5} \mathrm{cfu} / \mathrm{mL}$ phage $\mathrm{scFv}$ was selected for further investigation.

3.2. Sequencing and Complementarity-Determining Region Analysis. Sequencing the eight positive clones with specific primers found only three genes: $\mathrm{scFv} 13, \mathrm{scFv} 37$ and scFv81 that contained both VHCDR and VLCDR regions (Figure 2A). However, only scFv81 with the highest binding affinity was chosen for further study. The full-length sequence of scFv81 consisted of 248 amino acid residues with a predicted molecular weight of $27.2 \mathrm{kDa}$, including a flexible amino acid linker of Gly-Ser between the $\mathrm{VH}$ and VL regions. The homology identities and coverages for $\mathrm{VH}$ and VL were analyzed through the international ImMunoGeneTics information system (IMGT) (www.imgt.org), as shown in Table 1. $\mathrm{VH}$ was the closest to human $\mathrm{V}$ region frameworks by accession no. Z12367 Homsap IGHV4-38-2*01F with amino acid homology covering $100 \%$, calculated as a percentage of the identical residues for their FR1-3 sequences (a total of 120 residues). $\mathrm{VL}$ is closest to the human $\mathrm{V}$ region by accession no. X59315 Homsap IGKV1-39*01F with amino acid homology covering $92.03 \%$ for FR1 and $100 \%$ for FR2-3 (Table 1). The predicted CDR1, CDR2, and CDR3 of the $\mathrm{VH}$ domain were located at positions $27-35,53-59$, and $98-111$ in the primary sequence, while predictions of CDR1, CDR2, and CDR3 of the VL domain were specified at positions 164-169, 187-189, and 226-233, respectively, as depicted in Figure 2B. The 3D structure of $\mathrm{scFv}$ was modeled by SWISS-MODEL (Figure $2 \mathrm{C})$. The Ramachandran plot of the 3D model that indicated a 

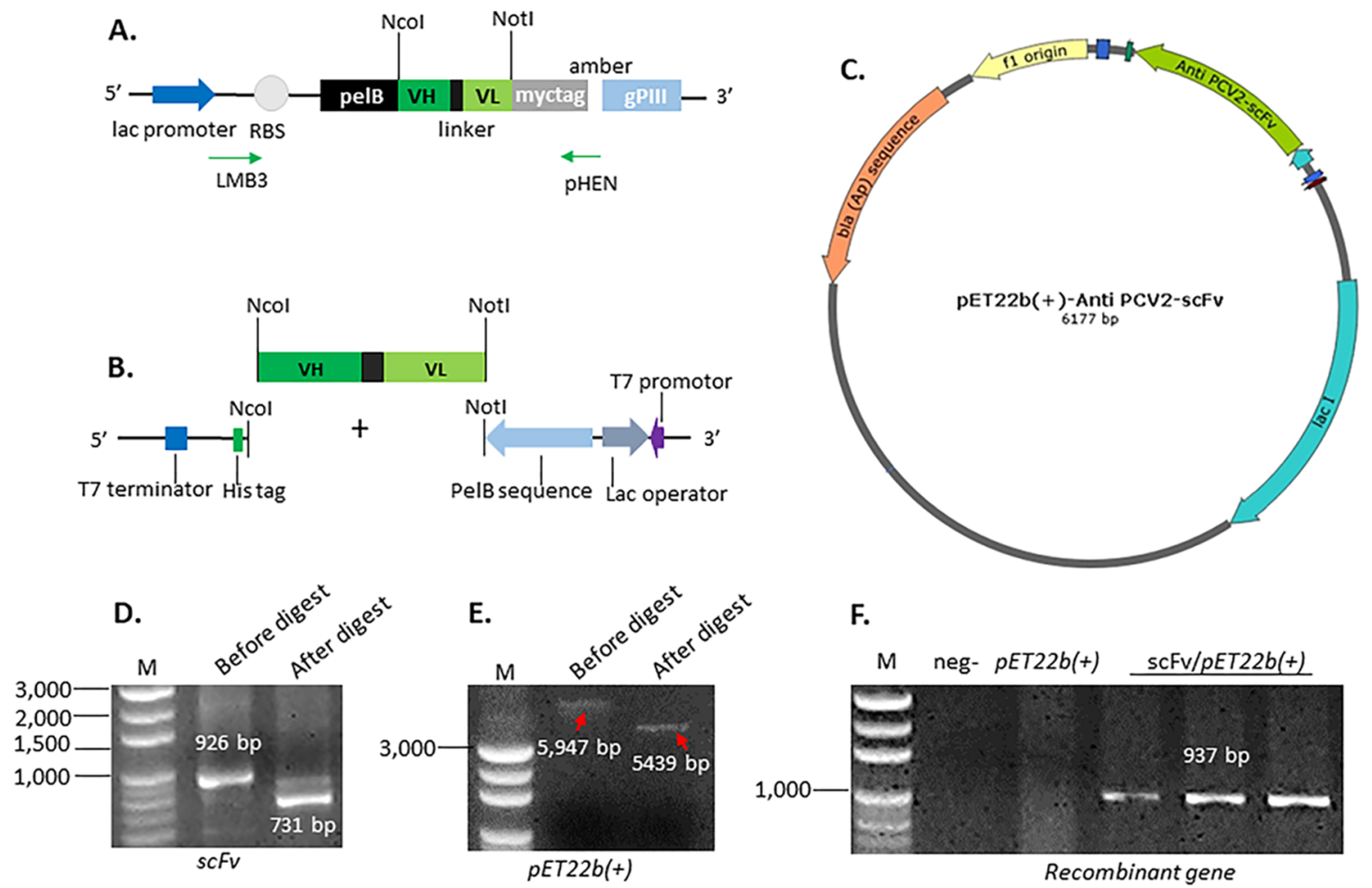

F.

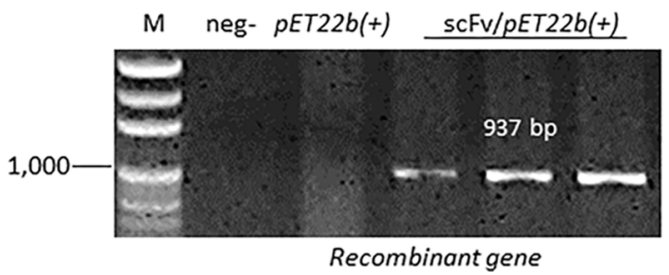

Figure 3. (A) Diagram of scFv in pIT2 phagemid. (B) Diagram of scFv ligation in $p E T 22 b(+)$ expression vector. (C) Map vector of recombinant $\mathrm{scFv} / p E T 22 b(+)$. (D) PCR product for scFv gene before $(926 \mathrm{bp})$ and after digestion $(731 \mathrm{bp})$. (E) PCR product for $p E T 22 b(+)$ before $(5947$ $\mathrm{bp}$ ) and after digestion (5439 bp). (F) PCR product for scFv ligated in pET22b (+) with size $937 \mathrm{bp}$. All PCR products were analyzed on $2 \%$ agarose gel.
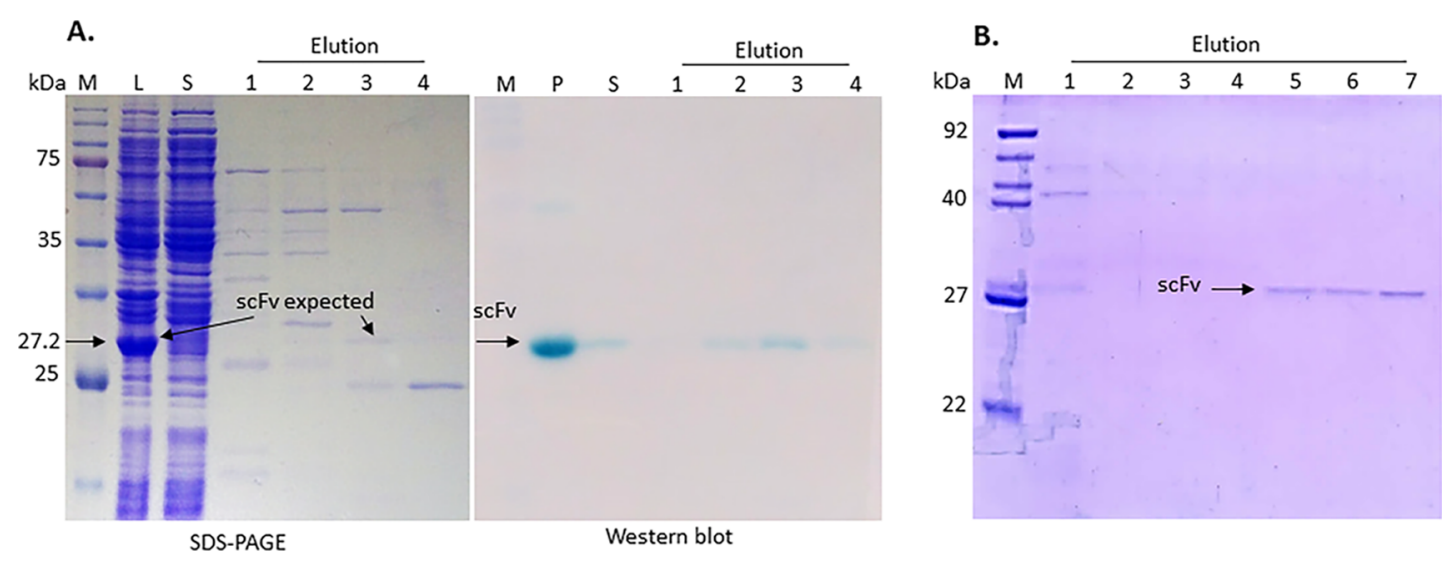

Figure 4. A) SDS-PAGE (left) and western blot (light) analysis of purified scFv using the $\mathrm{Ni}^{2+} \mathrm{NTA}$ column (M: protein marker, L: cell lysate, S: supernatant, 1-4: scFv fraction eluted by imidazole with concentrations 50, 100, 200, and $400 \mathrm{mM}$, respectively). scFv from SDS-PAGE detected by the western blot using the anti His antibody as $1^{\circ}$ antibody and anti-mouse IgG-HRP as $2^{\circ}$ antibody shown as the black arrow. (B) SDS-PAGE analysis of produced scFv purified by combining two columns: cation exchange and then $\mathrm{Ni}^{2+} \mathrm{NTA}$ as the second column (lanes 1-4: scFv faction eluted in $50 \mathrm{mM}$ of imidazole, lanes 5-7: scFv faction eluted in $100 \mathrm{mM}$ of imidazole).

concentration gradient of imidazole $(50-400 \mathrm{mM})$ and the size of $\mathrm{scFv}$ fragments was evaluated by SDS-PAGE with Coomassie Blue staining (Figure 4). Results showed high insoluble $\mathrm{scFv}$ in cell lysate compared to soluble $\mathrm{scFv}$ in the supernatant (with a band at $27.2 \mathrm{kDa}$ as expected) (Figure $4 \mathrm{~A})$. The $\mathrm{scFv}$ was confirmed by western blot analysis with anti-His antibody and presented the band as expected (Figure 4A). However, the scFv was contaminated by other proteins when using only the $\mathrm{Ni}^{2+}$ column. Thus, to remove the remaining contaminants, two columns of cation exchange followed by $\mathrm{Ni}^{2+} \mathrm{NTA}$ were performed. Single bands of scFv proteins with high purity appeared in imidazole concentration at $100 \mathrm{mM}$ (Figure 4B). Fractions of $\mathrm{scFv}$ were further dialyzed into PBS, while scFv concentration was determined at $0.121 \mathrm{mg} / \mathrm{mL}$ by a nanodrop spectrophotometer at $280 \mathrm{~nm}$.

3.5. Western Blot Analysis. To confirm the binding of $\mathrm{scFv}$, the PCV2 capsid was loaded in equal protein (150 ng/ well) in 4 wells of SDS-PAGE; one for Coomassie Blue staining as positive control protein and three for western blotting and probed with different antibodies of purified scFv, phage scFv, and commercial anti PCV2 antibody. Results showed that SDS-PAGE contained the PCV2 capsid with a molecular weight of $23.8 \mathrm{kDa}$ (Figure 5A). The purified $\mathrm{scFv}$ and phage scFv had specific binding to the PCV2 capsid, 


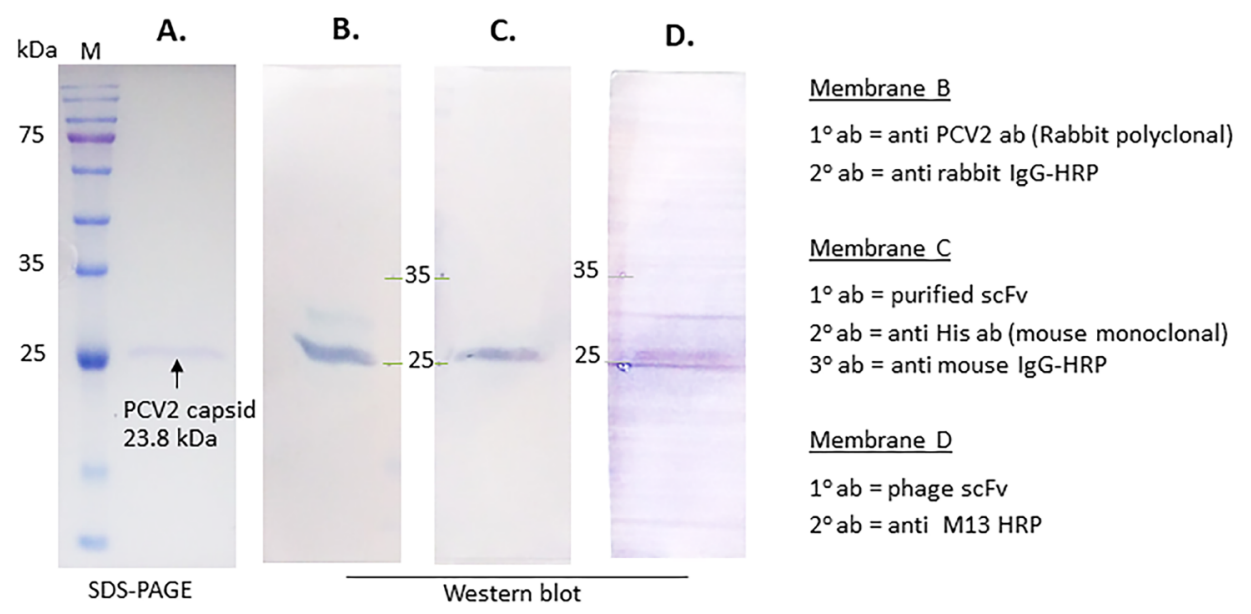

Figure 5. (A) SDS-PAGE analysis of PCV2 capsid protein $(28.3 \mathrm{kDa})$ as control showing western blotting with different antibody binding to the PCV2 capsid. (B) Commercial anti PCV2 antibody as positive control. (C) Purified scFv. (D) Phage display scFv. Blue bands on membranes represent antibodies captured on the PCV2 capsid.

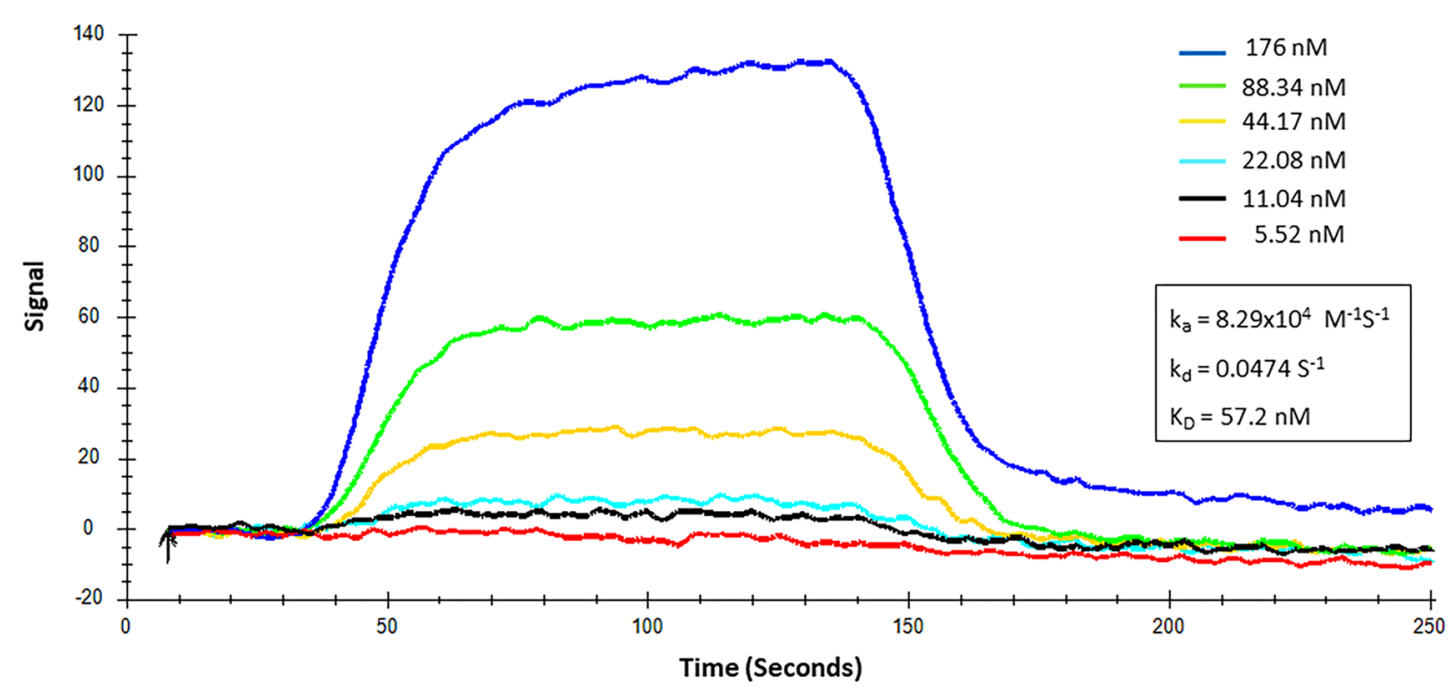

Figure 6. SPR sensorgrams of scFv binding to the PCV2 capsid. Different concentrations of the PCV2 capsid (from bottom to top); 5.52, 11.04, $22.08,44.17,88.34$, and $176 \mathrm{nM}$ were injected into the $\mathrm{NH}_{2}$ sensor chip coated with $200 \mu \mathrm{L}$ of scFv coupled with EDC and NHS. Data were fitted with a 1:1 Langmuir binding model using Trace Drawer version 1.6.1. Association rate $\left(k_{\mathrm{a}}\right)$, dissociation rate $\left(k_{\mathrm{d}}\right)$, and affinity binding $\left(K_{\mathrm{D}}\right)$ constants are shown as an inset box.

presenting in specific bands on western blot membranes (Figure 5C,D). This result of the probed PCV2 capsid with the anti PCV2 antibody (rabbit polyclonal) showed the specific band and one tiny non-specific band on the membrane (Figure 5B).

3.6. Kinetics and Affinity Determination by SPR. To evaluate the apparent affinities of purified $\mathrm{scFv}$ antibodies to the PCV2 capsid, binding kinetics using the immobilized scFv antibody were determined by SPR. The scFv was immobilized on an $\mathrm{NH}_{2}$ sensor chip through covalent interaction with the activated carboxyl functional group of scFv, allowed by injected difference concentration PCV2 capsids (5.52-176 nM). SPR binding profiles are presented in Figure 6. The scFv antibody displayed high binding affinity to the PCV2 capsid, with $K_{\mathrm{D}}$ values in the nanomolar range $(57.2 \mathrm{nM})$ and exhibited parameters with association rate $\left(k_{\mathrm{a}}\right)=8.29 \times 10^{4} \mathrm{M}^{-1} \mathrm{~S}^{-1}$ and dissociation rate $\left(k_{\mathrm{d}}\right)=0.0474 \mathrm{~S}^{-1}$.

3.7. Impedimetric Immunosensor. The purified $\mathrm{scFv}$ was applied for the immunosensor based on EIS for detection of the PCV2 capsid. Quantitative behavior of the immuno- sensor was assessed by measuring the electron transfer resistance $\left(R_{\mathrm{et}}\right)$ of different concentrations of the PCV2 capsid. The immunosensor was performed according to Figure $7 \mathrm{~A}$, which shows the modification steps of gold electrodes with DSP, scFv antibody, and PCV2 capsid, respectively. The impedance spectra were characterized by modified processes on the electrode, with results presented as Nyquist plots in Figure $7 \mathrm{~B}$ using bare gold electrodes (curve a, $R_{\mathrm{et}}=42 \Omega$ ). The gold electrodes were further attached by DSP (curve b, $R_{\mathrm{et}}=$ $138 \Omega$ ), scFv immobilized (curve c, $R_{\mathrm{et}}=167 \Omega$ ), and the $R_{\mathrm{et}}$ value increased. The scFv/DSP/gold electrodes were further incubated with PCV2 capsid, and the $R_{\text {et }}$ value increased significantly (curve c, $R_{\mathrm{et}}=234 \Omega$ ). Figure $7 \mathrm{C}$ shows that the EIS signal increased with increasing PCV2 capsid concentration from 35, 176, 352, and $704 \mathrm{nM}$, with $R_{\mathrm{et}}$ values increasing as $323,359,419$, and $546 \Omega$, respectively. A plot of the $\Delta R_{\text {et }}$ value against the concentration of the PCV2 capsid in the range 35-704 $\mathrm{nM}$ exhibited a linear relationship with a correlation coefficient of 0.9963 and LOD $=114 \mathrm{nM}$ (Figure 7D). These experimental results confirmed the feasibility of the 


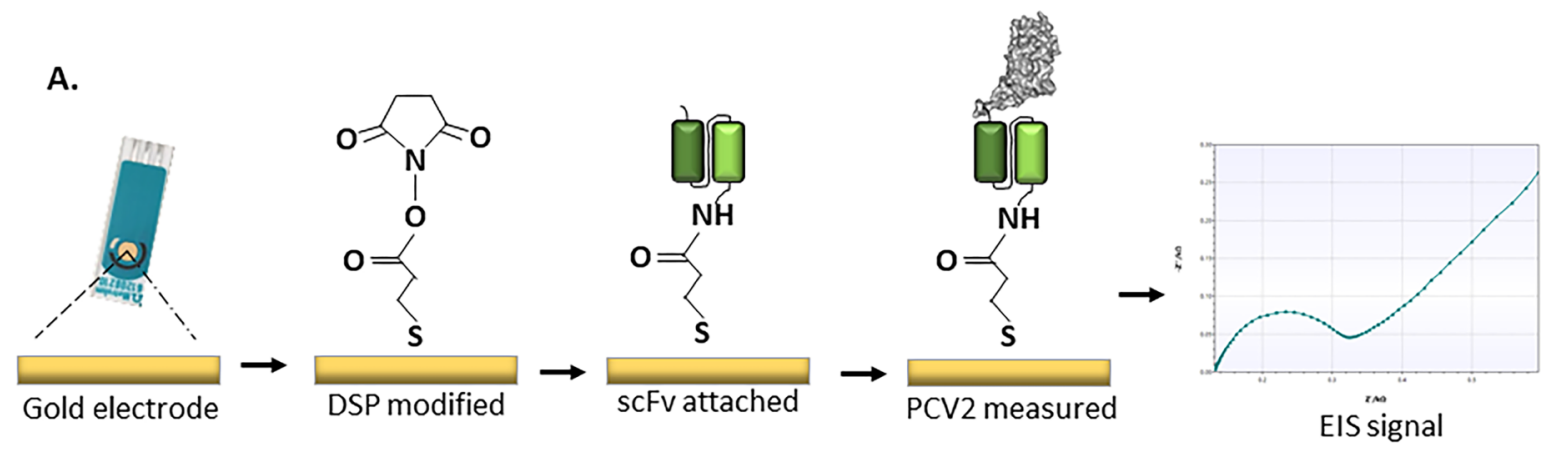

B.

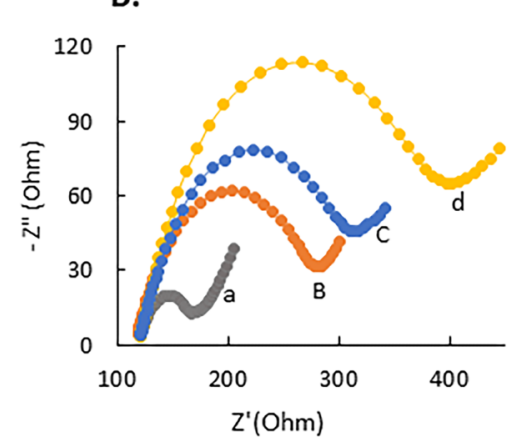

C.

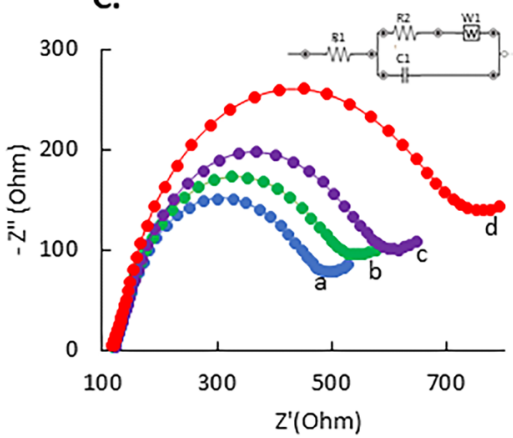

D.

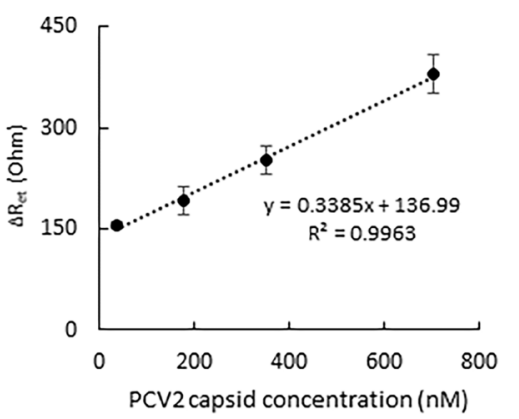

Figure 7. (A) Schematic illustration of the impedimetric immunosensor fabrication process. (B) EIS response for characterization of (a) bare gold electrode, then treatment with (b) DSP, (c) scFv, and (d) PCV2 capsid. (C) EIS signal of the immunosensor-measured PCV2 capsid at different concentrations (a) 35, (b) 176, (c) 352, and (d) $704 \mathrm{nM}$. Impedance spectra were analyzed by fitting them to an equivalent electrical circuit model (inset C). (D) Linear correlation between relative resistance and PCV2 capsid concentration within the range of 35 to $704 \mathrm{nM}\left(R^{2}=0.9963\right)$. EIS was conducted in $5 \mathrm{mM}\left[\mathrm{Fe}\left(\mathrm{CN}_{6}\right)\right]^{3-/ 4-}$ within the frequency range of $0.01 \mathrm{~Hz}$ to $100 \mathrm{kHz}$.

proposed immunosensor using $\mathrm{scFv}$ as a probe for the diagnosis of the PCV2 capsid.

\section{DISCUSSION}

PCV2 infection is associated with many diseases. Globally, PCVADs have a serious economic impact on the swine industry. ${ }^{3,5}$ Thus, effective strategies for rapid detection of PCV2 will help veterinarians and farmers to generate information that can be used to assess clinical disease and make epidemiological decisions to evaluate farm stability and establish vaccines and biosecurity programs.

Phage display screening has previously been used for selecting the specific binder to the PCV2 capsid, but different libraries exist such as peptide libraries ${ }^{38-40}$ and Bactrian camel sdAb library. ${ }^{41-43}$ This study used human scFv library. The single-domain antibody ( $\mathrm{sdAb}$ ) has smaller fragments with size $15 \mathrm{kDa}^{44}$ consisting of either $\mathrm{VH}$ or $\mathrm{VL}$ domains, while scFv consists of both $\mathrm{VH}$ and $\mathrm{VL}$ with a size of $28 \mathrm{kDa}$. In terms of phage display, the small antibody format ( $\mathrm{sdAb}, \mathrm{scFv}$ ) is preferred because of the ease for packaging the new phage particles and expression compared to full immunoglobulin, which is large sized and not suitable for E. coli. ${ }^{45}$ Tomlinson I + $\mathrm{J}$ libraries are widely used, based on $\mathrm{scFv}$ format with diversity of 18 amino acids incorporated in CDRs 2 and 3 in positions involved in antigen binding, and are highly diverse in the natural repertoire. Many studies used this library, and their antibody showed high specificity and binding affinity to the targets. $^{46-48}$

Selection of $\mathrm{scFv}$ against the PCV2 capsid by phage display screening was successful in the first round of panning. The bounded phage infected E. coli XL1-Blue, and subsequently put on $2 x T Y$ agar plate allowed to the monoclonal scFv. Screening of positive clones from libraries generally require at least three to seven rounds of biopanning to select specifically binding clones. ${ }^{49,50}$ However, we performed panning in triplicate and found approximately 20 individual clones on each plate.

In sequencing and complementary-determining region (CDR) analysis, CDRs form part of the variable chains in immunoglobulins (antibodies) that bind to their specific antigens. Variable regions of a polypeptide chain are composed of CDR1, CDR2, and CDR3 as the most variable. ${ }^{51}$ Our results showed different amino acids in CDRs of the three clones, and this may contribute to the clones binding to different epitopes on the PCV2 capsid, as shown in the ELISA result (Figure $1 \mathrm{~A}$ ). Clone $\mathrm{scFv} 81$ gave the highest reactivity and was constructed into the $p E T 22 b(+)$ expression vector. Our recombinant $\mathrm{scFv} / p E T 22 b(+)$ was first transformed into the $E$. coli DH5 $\alpha$ competent cell and subsequently into $E$. coli BL21 because $E$. coli DH5 $\alpha$ strain growth is faster than $E$. coli BL21. E. coli DH5 $\alpha$ has recA mutation; it does not show heterologous recombination, and this ensures higher insert stability.

The abilities of the scFv binding PCV2 capsid were evaluated by Western blotting (Figure 5). Purified $\mathrm{scFv}$ and phage $\mathrm{scFv}$ specific capturing to PCV2 capsid by size $23.8 \mathrm{kDa}$ were displayed on the PVDF membrane. These results were similar to using the anti PCV2 capsid antibody as the control. This suggested that the purified $\mathrm{scFv}$ bound specifically to the PCV2 capsid and was effective for diagnostics development. SPR analysis has been widely used to study interactions between immobilized biomolecules on sensor chip and solution-phase analytes. Our scFv showed good binding 
affinity to PCV2 in the nanomolar range $(57.2 \mathrm{nM})$, probably because of the long VHCDR3 loop (Figure 2) as the main factor that determined the character of high binding affinity. Our binding affinities of $\mathrm{scFv}$ to PCV2 capsid were similar in the nanomolar range with $\mathrm{Hu}\left(K_{\mathrm{D}}=40 \mathrm{ng} / \mathrm{mL}, 952 \mathrm{nM}\right)$ with used full length of the anti-PCV2 antibody. ${ }^{21}$ Yang $\left(K_{\mathrm{D}}=49.4\right.$ $\mathrm{nM})^{43}$ observed kinetics binding by using sdAb. Hao $\left(K_{\mathrm{D}}=\right.$ $103 \mathrm{nM})^{39}$ and Zheng $\left(K_{\mathrm{D}}=98.5 \mathrm{nM}\right)^{38}$ observed kinetics binding using peptides against PCV2. However, no report has evaluated the binding affinity of the scFv antibody to PCV2 using SPR analysis. Our protein-protein docking analysis confirmed the strong binding of scFv with the PCV2 capsid using several interaction bonds including hydrophobic, hydrogen bond, and aromatic and cation-pi interaction.

Previously, scFvs have been used in electrochemical immunosensors based on EIS for detection of many targets such as prostate specific antigen ${ }^{31}$ and toxic microalgae Alexandrium minutum ${ }^{32}$-accepted PCV2 capsid. Here, scFv was applied on gold electrodes as an immunosensor to detect the PCV2 capsid by measuring electrode transfer resistance changes. EIS fabrication is simple with little time required to prepare scFv-attached electrodes. DSP, a protein crosslinker, was first attached on the gold electrode via a disulfide bond and then reacted with $\alpha$-amine at the $\mathrm{N}$-terminal of the scFv antibody. ${ }^{53}$ The EIS spectra, presented as Nyquist plots, showed increasing impedance when components changed in each step of modification (Figure 7B) because transfer resistance at the electrode surface gradually increased. Thus, in the measuring step, different concentrations of the PCV2 capsid were incubated with the scFv-modified electrode, corresponding to increase in electron transfer resistance (Figure $7 \mathrm{C}$ ). This result suggested $\mathrm{scFv}$ binding to the target with $\mathrm{LOD}=114 \mathrm{nM}(2.7 \mu \mathrm{g} / \mathrm{mL})$. There is no report that evaluated the sensitivity of the $\mathrm{scFv}$ antibody binding to PCV2 by the impedimetric immunosensor. Our study was compared to Luo's study. They developed a label-free, antibody-based PCV2 biosensor; Staphylococcus protein A (SPA) was employed to modify a silanized fiber surface to enhance the bioactivity of a specific anti-PCV2 antibody, resulting in LOD $=4.06 \mathrm{ng} / \mathrm{mL}(96 \mathrm{nM}) ;^{54}$ our LOD value is higher than of this immunoassay.

Our study demonstrated that $\mathrm{scFv}$ constructs provided improved binding affinity but also functioned as tracers of target antigens and signal transduction molecules in EIS immunosensor systems for PCV2 detection, with potential for diagnostic application of biosensors in the swine industry. However, the further study about the cross-reactive test, for example, test $\mathrm{scFv}$ activity with porcine reproductive and respiratory syndrome virus, pseudorabies virus, and also comparison PCV2 immunosensor with the standard method for PCV2 detection would be more reliable.

\section{CONCLUSIONS}

We successfully performed screening and isolation of $\mathrm{scFv}$ clones from Human Single Fold scFv libraries I $+\mathrm{J}$ against the PCV2 capsid. The recombinant $\mathrm{scFv}$ gene/pET22b (+) showed potential for use in antibody production of $E$. coli BL21. Binding behavior of $\mathrm{scFv}$ to the PCV2 capsid was evaluated by ELISA, western blot, and SPR. Results of SPR assays showed affinity binding of the scFv antibody to PCV2 capsid in the nanomolar range $\left(K_{\mathrm{D}}=57.2 \mathrm{nM}\right)$. Our preliminary investigation of $\mathrm{scFv}$ as an immunosensor based on EIS for PCV2 capsid detection with a modified gold electrode showed LOD in nanomolar range $(\mathrm{LOD}=114 \mathrm{nM})$. This suggested that $\mathrm{scFv}$ has the potential to perform as a $\mathrm{PCV} 2$ real virus. However, further research is required to confirm these findings..

\section{ASSOCIATED CONTENT}

\section{Supporting Information}

The Supporting Information is available free of charge at https://pubs.acs.org/doi/10.1021/acsomega.1c03894.

Planning phage display cycle to screen the scFv-specific PCV2 capsid, Ramachandran plot of the scFv-specific PCV2 capsid, interaction between $\mathrm{scFv}$ and the PCV2 capsid via hydrophobic interaction, main chain-side chain hydrogen, ionic interaction, aromatic-aromatic interaction, and cation-Pi interaction (PDF)

\section{AUTHOR INFORMATION}

\section{Corresponding Author}

Kiattawee Choowongkomon - Department of Biochemistry, Faculty of Science, Kasetsart University, Bangkok 10900, Thailand; 이이이.org/0000-0002-2421-7859; Phone: +66 25625555 ext. 2051; Email: kiattawee.c@ku.th; Fax: 025614627

\section{Authors}

Supaporn Klangprapan - Genetic Engineering Interdisciplinary Program, Graduate School, Kasetsart University, Bangkok 10900, Thailand

Chang-Ching Weng - Department of Applied Chemistry, National Chiao Tung University, Hsinchu 30010, Taiwan

Wan-Ting Huang - Department of Applied Chemistry, National Chiao Tung University, Hsinchu 30010, Taiwan

Yaw-Kuen Li - Department of Applied Chemistry, National Chiao Tung University, Hsinchu 30010, Taiwan; Center for Emergent Functional Matter Science, National Chiao Tung University, Hsinchu 30010, Taiwan

Complete contact information is available at: https://pubs.acs.org/10.1021/acsomega.1c03894

\section{Notes}

The authors declare no competing financial interest.

\section{ACKNOWLEDGMENTS}

This project was supported by Research and Researchers for Industries (RRI), the Thailand Research Fund (PHD60I0086). This research was also supported by the Postdoctoral Fellowship from Kasetsart University and Kasetsart University Research and Development Institutes (KURDI (FF(KU) 6.64)).

\section{ABBREVIATIONS}

ECL, enhanced chemiluminescence; CDR, complementaritydetermining region; CFU, colony forming unit; EIS, electrochemical impedance spectroscopy; ELISA, enzyme-linked immunosorbent assay; IPMA, immunoperoxidase monolayer assay; IPTG, isopropyl $\beta$-D-thiogalactopyranoside; $K_{\mathrm{D}}$, equilibrium dissociation constant; ORFs, open reading frames; PCV2, porcine circovirus type 2; PCVAD, porcine circovirusassociated disease; PDNS, porcine dermatitis and nephropathy syndrome; PMWS, post-weaning multisystemic wasting syndrome; PRDC, porcine respiratory disease complex; $R_{\mathrm{et}}$, electron transfer resistance; scFv, single-chain variable frag- 
ment; sdAb, single-domain antibody; SDS-PAGE, sodium dodecyl sulfate polyacrylamide gel electrophoresis; SPR, surface plasmon resonance; VHHs, single-domain variable heavy chain

\section{REFERENCES}

(1) Franzo, G.; Cortey, M.; de Castro, A. M. M. G.; Piovezan, U.; Szabo, M. P. J.; Drigo, M.; Segalés, J.; Richtzenhain, L. J. Genetic characterisation of Porcine circovirus type 2 (PCV2) strains from feral pigs in the Brazilian Pantanal: An opportunity to reconstruct the history of PCV2 evolution. Vet. Microbiol. 2015, 178, 158-162.

(2) Segalés, J.; Allan, G. M.; Domingo, M. Porcine circovirus diseases. Anim. Health Res. Rev. 2005, 6, 119-142.

(3) Xiao, C. T.; Halbur, P. G.; Opriessnig, T. Global molecular genetic analysis of porcine circovirus type 2 (PCV2) sequences confirms the presence of four main PCV2 genotypes and reveals a rapid increase of PCV2d. J. Gen. Virol. 2015, 96, 1830-1841.

(4) Qu, T.; Li, R.; Yan, M.; Luo, B.; Yang, T.; Yu, X. High prevalence of PCV2d in Hunan province, China: a retrospective analysis of samples collected from 2006 to 2016. Arch. Virol. 2018, 163, 18971906.

(5) Xia, D.; Huang, L.; Xie, Y.; Zhang, X.; Wei, Y.; Liu, D.; Zhu, H.; Bian, H.; Feng, L.; Liu, C. The prevalence and genetic diversity of porcine circovirus types 2 and 3 in Northeast China from 2015 to 2018. Arch. Virol. 2019, 164, 2435-2449.

(6) Aiki-Raji, C. O.; Adebiyi, A. I.; Oluwayelu, D. O. A Slaughterhouse Survey for Porcine Circovirus Type 2 in Commercial Pigs in Ibadan, Southwest Nigeria. Folia Vet. 2018, 62, 30.

(7) Afolabi, K. O.; Iweriebor, B. C.; Okoh, A. I.; Obi, L. C. Global Status of Porcine circovirus Type 2 and Its Associated Diseases in Sub-Saharan Africa. Adv. Virol. 2017, 2017, 1-16.

(8) Zhou, W.; Ullman, K.; Chowdry, V.; Reining, M.; Benyeda, Z.; Baule, C.; Juremalm, M.; Wallgren, P.; Schwarz, L.; Zhou, E.; Pedrero, S. P.; Hennig-Pauka, I.; Segales, J.; Liu, L. Molecular investigations on the prevalence and viral load of enteric viruses in pigs from five European countries. Vet. Microbiol. 2016, 182, 75-81.

(9) Neira, V.; Ramos, N.; Tapia, R.; Arbiza, J.; Neira-Carrillo, A.; Quezada, M.; Ruiz, A.; Bucarey, S. A. Genetic analysis of porcine circovirus type 2 from pigs affected with PMWS in Chile reveals intergenotypic recombination. Virol. J. 2017, 14, 191.

(10) Palinski, R.; Piñeyro, P.; Shang, P.; Yuan, F.; Guo, R.; Fang, Y.; Byers, E.; Hause, B. M. A novel porcine circovirus distantly related to known circoviruses is associated with porcine dermatitis and nephropathy syndrome and reproductive failure. J. Virol. 2017, 91, No. e01879.

(11) Segalés, J. Porcine circovirus type 2 (PCV2) infections: clinical signs, pathology and laboratory diagnosis. Virus Res. 2012, 164, 1019.

(12) Karuppannan, A.; Opriessnig, T. Porcine circovirus type 2 (PCV2) vaccines in the context of current molecular epidemiology. Viruses 2017, 9, 99.

(13) Wang, L.; Zhao, D.; Sun, B.; Yu, M.; Wang, Y.; Ru, Y.; Jiang, Y.; Qiao, X.; Cui, W.; Zhou, H.; Li, Y.; Xu, Y.; Tang, L. Oral vaccination with the porcine circovirus type $2(\mathrm{PCV}-2)$ capsid protein expressed by Lactococcus lactis induces a specific immune response against PCV-2 in mice. J. Appl. Microbiol. 2020, 128, 74-87.

(14) Opriessnig, T.; Xiao, C.-T.; Halbur, P. G.; Gerber, P. F.; Matzinger, S. R.; Meng, X.-J. A commercial porcine circovirus (PCV) type 2a-based vaccine reduces PCV2d viremia and shedding and prevents PCV2d transmission to naive pigs under experimental conditions. Vaccine 2017, 35, 248-254.

(15) Xi, X.; Mo, X.; Xiao, Y.; Yin, B.; Lv, C.; Wang, Y.; Sun, Z.; Yang, Q.; Yao, Y.; Xuan, Y.; Li, X.; Yuan, Y. A.; Tian, K. Production of Escherichia coli-based virus-like particle vaccine against porcine circovirus type 2 challenge in piglets: Structure characterization and protective efficacy validation. J. Biotechnol. 2016, 223, 8-12.

(16) Mo, X.; Li, X.; Yin, B.; Deng, J.; Tian, K.; Yuan, A. Structural roles of PCV2 capsid protein N-terminus in PCV2 particle assembly and identification of PCV2 type-specific neutralizing epitope. PLoS Pathog. 2019, 15, No. e1007562.

(17) Davies, B.; Wang, X.; Dvorak, C. M. T.; Marthaler, D.; Murtaugh, M. P. Diagnostic phylogenetics reveals a new porcine circovirus 2 cluster. Virus Res. 2016, 217, 32-37.

(18) Woźniak, A.; Miłek, D.; Matyba, P.; Stadejek, T. Real-Time PCR Detection Patterns of Porcine Circovirus Type 2 (PCV2) in Polish Farms with Different Statuses of Vaccination against PCV2. Viruses 2019, 11, 1135.

(19) Huang, L.; Wei, Y.; Xia, D.; Liu, D.; Zhu, H.; Wu, H.; Feng, L.; Liu, C. A broad spectrum monoclonal antibody against porcine circovirus type 2 for antigen and antibody detection. Appl. Microbiol. Biotechnol. 2019, 103, 3453-3464.

(20) Rai, V.; Upmanyu, V.; Mohd, G.; Kumar, R.; Koppad, S.; Ansari, A.; Bora, D. P.; Pandey, A. B.; Dhar, P.; Tiwari, A. K. Comparing the efficiency of different Escherichia coli strains in producing recombinant capsid protein of porcine circovirus type 2 . Mol. Cell. Probes 2020, 52, 101556.

(21) Hu, J.; Wang, T.; Wang, S.; Chen, M.; Wang, M.; Mu, L.; Chen, H.; Hu, X.; Liang, H.; Zhu, J.; Jiang, M. Development of a surface plasmon resonance biosensing approach for the rapid detection of porcine circovirus type2 in sample solutions. PLoS One 2014, 9, No. e111292.

(22) Smith, G. Filamentous fusion phage: novel expression vectors that display cloned antigens on the virion surface. Science 1985, 228, 1315-1317.

(23) Thokala, R.; Olivares, S.; Mi, T.; Maiti, S.; Deniger, D.; Huls, H.; Torikai, H.; Singh, H.; Champlin, R. E.; Laskowski, T.; McNamara, G.; Cooper, L. J. N. Redirecting specificity of T cells using the sleeping beauty system to express chimeric antigen receptors by mix-and-matching of $\mathrm{VL}$ and $\mathrm{VH}$ domains targeting $\mathrm{CD} 123+$ tumors. PLoS One 2016, 11, No. e0159477.

(24) Xu, C.; Zhang, C.; Zhong, J.; Hu, H.; Luo, S.; Liu, X.; Zhang, X.; Liu, Y.; Liu, X. Construction of an immunized rabbit phage display library for selecting high activity against Bacillus thuringiensis Cry $1 \mathrm{~F}$ toxin single-chain antibodies. J. Agric. Food Chem. 2017, 65, 60166022.

(25) Fahimi, F.; Sarhaddi, S.; Fouladi, M.; Samadi, N.; Sadeghi, J.; Golchin, A.; Tohidkia, M. R.; Barar, J.; Omidi, Y. Phage displayderived antibody fragments against conserved regions of VacA toxin of Helicobacter pylori. Appl. Microbiol. Biotechnol. 2018, 102, 68996913.

(26) Bagheri, S.; Yousefi, M.; Safaie Qamsari, E.; Riazi-Rad, F.; Abolhassani, M.; Younesi, V.; Dorostkar, R.; Movassaghpour, A. A.; Sharifzadeh, Z. Selection of single chain antibody fragments binding to the extracellular domain of $4-1 \mathrm{BB}$ receptor by phage display technology. Tumor Biol. 2017, 39, 1010428317695924.

(27) Raeisi, H.; Safarnejad, M. R.; Moeini, P.; Safarpour, H.; Sokhansanj, Y. Isolation of single-chain variable fragment $(\mathrm{scFv})$ antibodies for detection of Chickpea chlorotic dwarf virus (CpCDV) by phage display. Arch. Virol. 2020, 165, 2789-2798.

(28) Cho, I.-H.; Kim, D. H.; Park, S. Electrochemical biosensors: perspective on functional nanomaterials for on-site analysis. Biomater. Res. 2020, 24, 6.

(29) Muñoz, J.; Montes, R.; Baeza, M. Trends in Electrochemical Impedance Spectroscopy involving nanocomposite transducers: characterization, architecture surface and bio-sensing. TrAC, Trends Anal. Chem. 2017, 97, 201-215.

(30) Cardinell, B. A.; Spano, M. L.; La Belle, J. T. Toward a LabelFree Electrochemical Impedance Immunosensor Design for Quantifying Cortisol in Tears. Crit. Rev. Bioeng. 2019, 47, 207-215.

(31) Spain, E.; Gilgunn, S.; Sharma, S.; Adamson, K.; Carthy, E.; O'Kennedy, R.; Forster, R. J. Detection of prostate specific antigen based on electrocatalytic platinum nanoparticles conjugated to a recombinant scFv antibody. Biosens. Bioelectron. 2016, 77, 759-766.

(32) Oloketuyi, S.; Mazzega, E.; Zavašnik, J.; Pungjunun, K.; Kalcher, K.; de Marco, A.; Mehmeti, E. Electrochemical immunosensor functionalized with nanobodies for the detection of the toxic microalgae Alexandrium minutum using glassy carbon electrode 
modified with gold nanoparticles. Biosens. Bioelectron. 2020, 154, 112052.

(33) Kaushik, A.; Yndart, A.; Kumar, S.; Jayant, R. D.; Vashist, A.; Brown, A. N.; Li, C.-Z.; Nair, M. A sensitive electrochemical immunosensor for label-free detection of Zika-virus protein. Sci. Rep. 2018, 8, 9700.

(34) Dip Gandarilla, A. M.; Regiart, M.; Bertotti, M.; Correa Glória, J.; Morais Mariuba, L. A.; Ricardo Brito, W. One-step enzyme-free dual electrochemical immunosensor for histidine-rich protein 2 determination. RSC Adv. 2021, 11, 408-415.

(35) Ramírez-Aportela, E.; López-Blanco, J. R.; Chacón, P. FRODOCK 2.0: fast protein-protein docking server. Bioinformatics 2016, 32, 2386-2388.

(36) Chinnadayyala, S. R.; Park, J.; Kim, Y. H.; Choi, S. H.; Lee, S.M.; Cho, W. W.; Lee, G.-Y.; Pyun, J.-C.; Cho, S. Electrochemical Detection of C-Reactive Protein in Human Serum Based on SelfAssembled Monolayer-Modified Interdigitated Wave-Shaped Electrode. Sensors 2019, 19, 5560.

(37) Cordeiro, T. A. R.; Gonçalves, M. V. C.; Franco, D. L.; Reis, A. B.; Martins, H. R.; Ferreira, L. F. Label-free electrochemical impedance immunosensor based on modified screen-printed gold electrodes for the diagnosis of canine visceral leishmaniasis. Talanta 2019, 195, 327-332.

(38) Zheng, G.; Lu, Q.; Wang, F.; Jin, Q.; Teng, M.; Zhang, N.; Ren, T.; Ding, P.; Zhang, G. Selection of affinity peptides for the purification potential of porcine circovirus type 2 (PCV2) Cap viruslike particles (VLPs). RSC Adv. 2017, 7, 38911-38914.

(39) Hao, J.; Wang, F.; Xing, G.; Liu, Y.; Deng, R.; Zhang, H.; Cheng, A.; Zhang, G. Design and preliminary application of affinity peptide based on the structure of the porcine circovirus type II Capsid (PCV2 Cap). PeerJ 2019, 7, No. e8132.

(40) Santos, M. R.; Assao, V. S.; Santos, F. d. A. A.; Salgado, R. L.; Carneiro, A. P.; Fietto, J. L. R.; Bressan, G. C.; de Almeida, M. R.; Lobato, Z. I. P.; Ueira-Veira, C.; Goulart, L. R.; Silva-Júnior, A. Utilization of phage display to identify antigenic regions in the PCV2 capsid protein for the evaluation of serological responses in mice and pigs. Arch. Virol. 2018, 163, 1877-1887.

(41) Yang, S.; Shang, Y.; Yin, S.; Tian, H.; Chen, Y.; Sun, S.; Jin, Y.; Liu, X. Selection and identification of single-domain antibody fragment against capsid protein of porcine circovirus type 2 (PCV2) from C. bactrianus. Vet. Immunol. Immunopathol. 2014, 160, 12-19.

(42) Fu, X.; Gao, X.; He, S.; Huang, D.; Zhang, P.; Wang, X.; Zhang, S.; Dang, R.; Yin, S.; Du, E.; Yang, Z. Design and selection of a camelid single-chain antibody yeast two-hybrid library produced de novo for the cap protein of porcine circovirus type 2 (PCV2). PLoS One 2013, 8, No. e56222.

(43) Yang, S.; Shang, Y.; Yin, S.; Wang, D.; Cai, J.; Gong, Z.; Serge, M.; Liu, X. A phage-displayed single domain antibody fused to alkaline phosphatase for detection of porcine circovirus type 2. J. Virol. Methods 2015, 213, 84-92.

(44) Ponsel, D.; Neugebauer, J.; Ladetzki-Baehs, K.; Tissot, K. High affinity, developability and functional size: the holy grail of combinatorial antibody library generation. Molecules 2011, 16, $3675-3700$

(45) Hust, M.; Dübel, S. Mating antibody phage display with proteomics. Trends Biotechnol. 2004, 22, 8-14.

(46) Perween, R.; Ahmed, S.; Shrivastava, T.; Parray, H. A.; Singh, B.; Pindari, K. S.; Sharma, C.; Shukla, S.; Sinha, S.; Panchal, A. K.; Kumar, R. A rapid novel strategy for screening of antibody phage libraries for production, purification, and functional characterization of amber stop codons containing single-chain antibody fragments. Biotechnol. Prog. 2021, 37, No. e3136.

(47) Gandhi, S.; Banga, I.; Maurya, P. K.; Eremin, S. A. A gold nanoparticle-single-chain fragment variable antibody as an immunoprobe for rapid detection of morphine by dipstick. RSC $A d v .2018,8$, 1511-1518.

(48) Alibeiki, M.; Golchin, M.; Tabatabaei, M. Development of a double-recombinant antibody sandwich ELISA for quantitative detection of epsilon toxoid concentration in inactivated Clostridium perfringens vaccines. BMC Vet. Res. 2020, 16, 361.

(49) Khajeh, S.; Tohidkia, M. R.; Aghanejad, A.; Mehdipour, T.; Fathi, F.; Omidi, Y. Phage display selection of fully human antibody fragments to inhibit growth-promoting effects of glycine-extended gastrin 17 on human colorectal cancer cells. Artif. Cells, Nanomed., Biotechnol. 2018, 46, 1082-1090.

(50) Phatsaman, J.; Hongprayoon, R.; Mahakarnjanagul, W. Construction and characterization of single chain variable fragmentalkaline phosphatase for rapid detection of aflatoxin B1 in an ELISAbased assay. J. Int. Soc. Southeast Asian Agric. Sci. 2017, 23, 79.

(51) Xu, J. L.; Davis, M. M. Diversity in the CDR3 region of $\mathrm{V}(\mathrm{H})$ is sufficient for most antibody specificities. Immunity 2000, 13, 37-45.

(52) Phue, J.-N.; Lee, S. J.; Trinh, L.; Shiloach, J. Modified Escherichia coli B (BL21), a superior producer of plasmid DNA compared with Escherichia coli K (DH5alpha). Biotechnol. Bioeng. 2008, 101, 831-836.

(53) Zheng, Q.; Zhang, H.; Tong, L.; Wu, S.; Chen, H. Cross-linking electrochemical mass spectrometry for probing protein three-dimensional structures. Anal. Chem. 2014, 86, 8983-8991.

(54) Luo, B.; Wu, S.; Zou, W.; Zhang, Z.; Zhao, M.; Shi, S.; Liu, Y.; Xi, X.; Zeng, Z.; Liang, W.; Yan, Z.; Zhang, L. Label-free immunoassay for porcine circovirus type 2 based on excessively tilted fiber grating modified with staphylococcal protein A. Biosens. Bioelectron. 2016, 86, 1054-1060. 